To cite this article please use the following reference:

Seetaram N., Forsyth P., and Dwyer L (2016). "Measuring price elasticities of demand for outbound tourism using competitiveness indices" accepted at Annals of Tourism Research 56(1), pp. 65-79.

\title{
MEASURING PRICE ELASTICITIES OF DEMAND FOR OUTBOUND TOURISM USING COMPETITIVENESS INDICES
}

\author{
Dr. Neelu Seetaram \\ Corresponding author \\ (nseetaram@bournemouth.ac.uk) \\ Professor Peter Forsyth \\ (Peter.forsyth@monash.edu) \\ Professor Larry Dwyer \\ (l.dwyer@unsw.edu)
}

\begin{abstract}
The real exchange rate (REX) has long been used as the proxy for prices in tourism demand models. However it has limitations, particularly when it comes to models of outbound tourism. As an alternative, a price competitiveness index (PCI) is developed and used as a proxy for prices in a model of outbound tourism from Australia. Results obtained show that while REX is statistically insignificant and yields a price elasticity of -0.002 , PCI is significant and generates a price elasticity of -1.07 . The results obtained show that PCI outperforms REX as the preferred price variable in modelling outbound demand on both theoretic and empirical grounds. Furthermore, this index can be used to monitor the inter-temporal competitiveness of a destination.
\end{abstract}

Keywords: Price Competitiveness Index, Outbound Tourism, Dynamic Panel Data, Price Elasticity, Australia. 


\section{MEASURING PRICE ELASTICITIES OF DEMAND FOR OUTBOUND TOURISM USING COMPETITIVENESS INDICES}

\section{Introduction}

The notion of price elasticity of demand was developed by Alfred Marshall in his seminal work, the Principles of Economics in 1890. Today, the concept is central to microeconomic analysis of consumer demand. It is an essential tool in the analysis of demand for goods and services and the understanding of decision making processes related to pricing, investment and planning. Price elasticities of demand are essential to policy makers in their assessment of the impacts of existing and potential new fiscal and monetary policies on the consumption habits of households. In the case of tourism demand, price elasticities are used by destination managers to measure the effects of changes in prices on number of arrivals, expenditure per capita of travellers and number of nights spent at a destination. Such information is crucial for developing strategies and plans for the tourism industry. Price elasticities of demand are also the basis for calibrating economic models which appraise the likely consequences of demand and supply shocks on the economic contribution of tourism to a destination. They are fundamental to forecasting exercises as they indicate to the industry the potential effect of changes in prices on sales revenue.

The above may explain the relatively high volume of research which has been devoted to the development of tourism demand models and the estimation of price elasticities of demand. According to a study by Song and $\operatorname{Li}(2008)$, there were 420 published articles on these topics from 1960-2002. Since then, over a hundred more may be added to this list. Researchers, however, face considerable difficulties in deciding on an adequate measure of price in their demand models (Crouch 1992, 1994). Tourism prices may be decomposed into two main components: the transportation cost and the prices of goods and services consumed at the destination. Researchers typically separate these two types of prices in their modelling. The transportation cost for international tourism is more often than not measured by the price of an air ticket to the destination, and its coefficient yields the transport price elasticity of demand.

Finding a measure for the prices of goods and services at the destination is a more complex procedure. Ideally, the tourism price will include the prices of a bundle of goods and services consumed by the representative tourist at the destination. The resulting set of prices, if included separately, will result in an 'intractable' model (Crouch, 1994). As a consequence, composite 
prices in the form of ratios of prices at the destination to those of the home countries are constructed and used ( $\mathrm{Li}$ et al., 2005). The underlying assumption is that the potential traveller will compare these prices in local currency and prices prevailing in the home country when making the travel decision. The relative prices converted to the home country currency are referred to as the tourism price index. The construction of tourism price indices are often hampered by lack of data on the actual good and services consumed by tourists and their prices (Dwyer et al, 2000; Dwyer and Forsyth, 2011; Forsyth and Dwyer, 2009). The real exchange rate (REX) has been put forward as an adequate approximation to changes in the relative prices that tourists face. REX is the most commonly used proxy for prices in tourism demand models (Song and Li, 2008).

\subsection{Objections to Using REX}

In spite of its widespread use, there are important objections to using the REX as a price proxy. The conceptual limitation to using the REX as a price proxy is that it must be capable of measuring how costly destinations are to visit. It cannot do this- the REX can measure the change in prices over a period, but not the absolute level of prices. It does not measure the relative prices of goods and services in different countries as it does not go beyond changes in prices, and does not determine whether a country is more or less price competitive than another at a particular point of time. However, to estimate demand elasticities, it is necessary to measure the absolute level, not just the change. This is a fundamental requirement when estimating demand functions. The REX cannot tell us, for example, whether prices in Norway are different from prices in India, at a point of time. To measure the level, as opposed to simply trends in tourism prices, cross-sectional studies using the prices paid by tourists in different countries are needed (Dwyer et al., 2000).

This problem shows up in empirical work. Studies such as Song et al. (2000), Halicioglu (2010) and Seo et al. (2009) provide the evidence of a strong cointegrating relationship between outbound tourism and REX and Seetaram et al. (2014) found significant price elasticities in five out of ten destinations for UK outbound travellers using real exchange rate. This variable has nevertheless not always performed satisfactorily as a proxy for prices in demand models for outbound tourism. This is illustrated, for example, in studies of demand from Australia, such as those of the Bureau of Transport and Communication Economics 
(BTCE) (1995), Smith and Toms (1978), Philips and Hamal (2000), Seetaram (2012b) and Yap (2013). Income and prices are normally expected to be the primary determinants of demand. A statistically insignificant price variable and a value very close to zero may lead to the conclusion that travellers are not susceptible to changes in prices. The situation is not straightforward, however. Some tourists may use the exchange rate as an available proxy given lack of information about local prices, while others may adjust their purchasing behaviour upon arrival at a destination to account for unexpected price levels. This may be a short term response while tourists adjust to new prices, though it will mean that the REX will have some impact on behaviour.

There are other objections. In open economies, the REX and income are inevitably determined by the country's volume of international trade. Both variables are likely to be influenced by the monetary and fiscal policies targeting the trade balance. For example, in Australia, the appreciation and subsequent fall of the dollar is to a large extent attributed to a mining boom (now moderating) which the country has been experiencing. On the other hand, the expansion of the mining sector is a major driver of the growth of the gross national product of the country. In this context, the assumption that the REX and the income of the country are independent and identically distributed may be a strong one. The outcome for the demand model is that the inclusion of an income variable, as well as the exchange rate, leads to a situation where the former variable encompasses the effect of the latter, thus attenuating its elasticity coefficient. Such an effect is consistent with recent analysis of the effect of Australia's mining export boom on tourism whereby a spending effect and a resource movement effect are argued to play interdependent roles in affecting different tourism market segments (Forsyth and Seetaram, 2014). Consistently with this, the REX is systematically found to be insignificant in explaining the number of departures in studies such BTCE (1995), Philips and Hamal (2000), Seetaram (2012b), Smith and Toms (1978) and Yap (2013), while income is found to be the most important determinant of international travel. In Yap (2013) for example, the author finds real exchange rate to the insignificant in explaining outbound travel for Holiday, VFR and Business but significant in for domestic tourism. In Cheng et al. (2013) the authors conclude that real exchange is not cointegrated with tourism import in the US. In order to address the issue of potential lack of independence between the income and price variable, an alternative proxy is needed. 
This study develops a price competitiveness index (PCI) which satisfies the above requirements. The proposed index is based on a comparison of the relative competitiveness of the destination to that of the home country. The method for developing the PCI is explained in Section 2 of this paper. In Section 3, a demand model for outbound tourism is formulated using the dynamic panel data technique. This is a robust technique which is widely used in the tourism context and ensures that results obtained are reliable (Seetaram, 2010, 2012a; Seetaram and Petit, 2012). As yet, competitiveness indices have not been widely used as a price variable in tourism demand analysis, though they are beginning to be used (see, Athanasopoulos et al., 2014; Dwyer et al., 2014, Forsyth et al 2012 and Etzo et al., 2014). To illustrate the superiority of PCI over the REX, the model is estimated using each separately as the proxy for prices. The results from the two estimations are compared and discussed in Section 4. Section 5 explores policy implications and issues for further research.

\section{Price in Models of Outbound Tourism}

\subsection{Real Exchange Rate}

Demand models for inbound tourism studies often consider the flow of visitors to one destination from a single source (and estimate using a time series). To obtain valid price elasticities, the model in question will contain the price of tourism at the selected destination (own price). There is one price ratio, between the origin and destination countries. Consider Australia as a destination. The own price of the international trip can be fairly accurately proxied by the relevant $\mathrm{REX}_{\mathrm{it}}$. This is calculated from the formula below:

$$
\mathrm{REX}_{\mathrm{it}}=\left[\frac{\mathrm{CPI}_{\mathrm{it}}}{\mathrm{CPI}_{\text {Aus }, \mathrm{t}}} \times \mathrm{EX}_{\mathrm{it}}\right]
$$

Where CPI is the consumer price index and EX is the exchange rate.

There are, however, differences in the modelling of inbound international tourism, as opposed to outbound international tourism. In studies of inbound tourism, the focus is very often on the prices in the origin and destination country. In studies of outbound tourism, researchers typically analyse departures from one country of origin to several destinations. Typically in such studies, there is an array of own prices and substitute prices in different countries (e.g. Coshall, 2005; Keating and Kriz, 2008; Seetaram et al. 2014; Song et al., 2000,). A model of international departures from Australia will contain as many own prices as there are destinations considered. This asymmetry may explain why the REX, which is a fair proxy for prices in model of 
international arrivals (when there is only one origin country- if there are several, the problem identified with outbound tourism occurs), fails to perform in models of international outbound tourism. In modelling outbound tourism, it is necessary to measure absolute prices and not just relative prices, as is the case with the REX.

To calculate the REX, a base year is selected when the prices are normalised to 100. For prices to be comparable across countries, the same base year is selected for all destinations. This is equivalent to assuming that in the base year, the price at the destination is the same for all travellers.

Taking this approach for outbound travel is incorrect. The assumption that, in the base year, travellers from the home country will face the same price irrespective of where they travel to, is inevitable when using the REX as the proxy for prices in models of outbound tourism. However, it is quite implausible. When one includes a price term in a demand function, it is normally understood that a good (or destination) which is more expensive to buy will have a higher proxy measure for price. This does not happen when one uses a proxy such as the REX. The REX does not contain any information about the absolute price of goods and services in the different destinations. It does not pick up the fact that prices in the UK are different from prices in Malaysia or India- in effect, using it assumes that UK, Malaysian and Indian prices are all the same in the base year. To estimate a demand function, one needs to have a measure of actual prices in different destinations. A competitiveness measure can provide this but a variable such as the REX cannot.

Moreover, the use of the REX implies that potential travellers react to changes in the price rather than the actual price level at the destination. Suppose that the Australian dollar appreciates by $10 \%$ against the British Pound and by 5\% against the Malaysian Ringgit, and that the inflation rates in all destinations are the same. For an Australian resident, the price of a trip to the UK will fall by more than that of the trip to Malaysia. The UK will become relatively cheaper than Malaysia, implying that demand may be expected to shift in favour of the UK. In absolute terms however, in spite of a higher value of the Australian dollar in British Pound, UK will still be a more expensive destination, due to the lower cost of living in Malaysia. Although on the margin, there would be a few potential travellers who will choose the UK which has become relatively less expensive, in general, it is unlikely that travellers will change their preferences in favour of 
the UK, which remains more expensive in absolute terms. Hence, the REX may not capture the price effect accurately in models of outbound tourism.

In addition to the central limitation of the REX, in open economies, the REX and income may not be strictly independent. These two variables are susceptible to fiscal and monetary policies which target the country's balance of payments account. This interdependence of the two variables is even more pronounced in the presence of Dutch Disease whereby the expansion of the export sector of the economy raises its GDP and puts an upward pressure on the international value of its currency (The Economist, 1977; Forsyth and Seetaram, 2014). The inclusion of a measure for income, and the REX as the price variable, may introduce multicollinearity in a demand model, the consequence of which is that the former variable encapsulates the effect of the latter. As a result, the REX will be found erroneously to have no effect on short term departures, which may lead researchers to conclude, inaccurately, that travellers do not react to changes in prices. The above situation is an additional reason why the REX is seen, systematically, to be statistically insignificant in models of outbound tourism using data from open economies (Seetaram, 2012b). Consequently, the literature on tourism demand modelling has struggled to generate accurate price elasticities of demand for outbound tourism for different countries.

\subsection{The Price Competitiveness Index}

This study develops an alternative proxy for prices at a destination in the form of a PCI which measures the relative price competitiveness of the destination. Major advantages of this index are that it is simple to construct data published from by the World Bank (and other sources) and it is straightforward to interpret. It can be used to monitor the relative price competitiveness of destinations and changes in these over time, and used as a proxy for price to estimate demand elasticities for tourism. These types of indices are often used in empirical work. For a recent tourism demand example, Athanasopoulos et al (2014) and Etzo, Massidda and Piras (2014) and.

The computation of this index takes into account the relative purchasing power parity (PPP) at the destination. The PPP theory was first developed by Gustav Cassell in 1918 and states that, in a competitive and free market situation, the relative value of two currencies is equivalent to the 
ratio of the prices of a basket of identical goods and services from the two countries. The basis for this theory is the 'law of one price' which states that, in an efficient market, all identical goods must have only one price. The example that follows illustrates this law.

Assume a situation with two hypothetical countries A and B, both selling good X. Let the price of good $\mathrm{X}$ be $\mathrm{P}_{\mathrm{xa}}$ in $\mathrm{A}$ and $\mathrm{P}_{\mathrm{xb}}$ in $\mathrm{B}$. In a simple model where both countries use the same currency, let good $\mathrm{X}$ be cheaper in $\mathrm{B}$ - that is $\mathrm{P}_{\mathrm{xa}}>\mathrm{P}_{\mathrm{xb}}$. In the absence of trade barriers and transportation costs, the two prices will converge as consumers from A will start purchasing $\mathrm{X}$ from $\mathrm{B}$ so that demand in country $\mathrm{B}$ will rise, increasing $\mathrm{P}_{\mathrm{xb}}$ and demand in country A will fall, reducing $\mathrm{P}_{\mathrm{xa}}$ until $\mathrm{P}_{\mathrm{xa}}=\mathrm{P}_{\mathrm{xb}}$. Introducing currency disparity into the model, let the currency of $\mathrm{B}$ (B\$) be valued at twice the currency of $\mathrm{A}(\mathrm{A} \$)$ - that is, $\mathrm{B} \$ 1=\mathrm{A} \$ 2$. Then, in order to compare prices, consumers will take into account the relative value of the respective currencies of their country. Consumers in $\mathrm{A}$ will purchase the commodity from $\mathrm{B}$ if and only if $\mathrm{P}_{\mathrm{xa}}>0.5 \mathrm{P}_{\mathrm{xb}}$. Suppose that the current market situation is such that $\mathrm{P}_{\mathrm{xa}}=0.9 \mathrm{P}_{\mathrm{xb}}$. Consumers from A will choose to purchase $\mathrm{X}$ in country $\mathrm{B}$, since the price paid for $\mathrm{X}$ in $\mathrm{B}$ will be lower when converted to $\mathrm{A} \$$ at the given exchange rate, than purchasing the commodity locally. This will boost demand for $\mathrm{B} \$$, causing an appreciation of $\mathrm{B} \$$, raising $\mathrm{P}_{\mathrm{xb}}$ for inhabitants of $\mathrm{A}$. The PPP theory stipulates that exchange rates between currencies are in equilibrium when their purchasing power is the same in each of the two countries. When a country's domestic price level is increasing, the exchange rate must depreciate in order to return to PPP.

There are, however, three main caveats to the above theory. First, transportation costs and barriers to trade can be significant; second, the market for goods and services must be competitive in both countries; and third, all goods are assumed to be tradable. These three factors are the reasons why, in reality, prices across countries differ considerably, necessitating adjustments when comparing price in demand models which incorporate data across countries. For international comparisons, price levels which have been adjusted for the discrepancy in the purchasing power of the currency in which they are quoted can be used to get a fairly accurate indication of the real income across countries (Forsyth and Dwyer, 2009). On its web site, the World Bank, which computes GDP at purchasing power parity for a number of countries, states that "By establishing purchasing power equivalence, where one dollar purchases the same quantity of goods and services in all countries, PPP conversions allow cross-country 
comparisons of economic aggregates on the basis of physical levels of output, free of price and exchange rate distortions."

Price competitiveness can be obtained by comparing unadjusted GDP with GDP adjusted for purchasing power parity. GDP, adjusted by market exchange rates, will not be an accurate measure of what a country's production can buy- normally purchasing power parity does not hold. Prices are different in different countries. To facilitate international comparisons, bodies such as the World Bank collect data on prices in different countries, and this enables estimates of GDP at internationally constant prices- GDP adjusted for PPP. To gain an estimate of prices in different countries, or the same country at different times, the unadjusted GDP can be compared to the PPP adjusted GDP. Both GDP and PPP adjusted GDP are readily available from sources such as the World Bank. Thus the price level in a particular country, i, at in period $\mathrm{t}$ is given by

$$
P_{i t}=\frac{Y_{i t}}{Y_{i t}^{p}}
$$

The relative prices can be used in this way to estimate a price competitiveness index (PCI). This can be used as a price variable in a demand function.

$$
\mathrm{PCI}_{\mathrm{ijt}}=\frac{\mathrm{P}_{\mathrm{it}}}{\mathrm{P}_{\mathrm{jt}}}
$$

The $\mathrm{PCI}_{\mathrm{ijt}}$ is a price competitiveness index, and the subscripts $\mathrm{i}$ and $\mathrm{j}$ are the destination and home country respectively. $\mathrm{PCI}_{\mathrm{ijt}}$ reflects the relative cost of living at the various destinations, making the international comparison of prices more effective. A rise in this index indicates that the destination is losing competitiveness, becoming relatively more expensive for international travellers. In this study, the index is calculated using Australia as the home country. In fact, tourism prices and general prices may not be equal. If this is the case, and tourism prices are very different from general prices, it would be advisable to construct a tourism specific PCI. This would be a very much bigger task. Fortunately, research has indicated that tourism prices are close to general prices (see Morley, 1994), and a general PCI is adequate except for very detailed work. 
To illustrate the differences between the PCI and the REX in indicating the price competitiveness of destinations, a table with four countries is drawn, including Indonesia, a developing country.

Table 1: Properties of Different Price Variables

\begin{tabular}{|l|c|c|c|c|}
\hline \multicolumn{1}{|c|}{ Year } & Australia & Germany & Indonesia & USA \\
\hline Unadjusted Exchange Rate $(\$ A=1)$ & & & & \\
\hline 1990 & 1.0 & 1.6 & 1438.8 & 0.78 \\
\hline 2008 & 1.0 & 1.18 & 8259.2 & 0.86 \\
\hline Exchange Rate Index (relative to \$A) & 100 & 100 & 100 & 100 \\
\hline 1990 & 100 & 074 & 574 & 110 \\
\hline 2008 & & & & 1.22 \\
\hline Competitiveness Index (relative to Australia prices) & 1.00 & 1.06 & 0.35 & 3.11 \\
\hline 1990 & 2.89 & 2.45 & 1.95 & 3 \\
\hline 2008 & & & & \\
\hline
\end{tabular}

The unadjusted exchange rate suggests that Indonesia is the most expensive of the destinations when, in reality, it simply means that Indonesia has a very low unit of exchange. The exchange rate index is less of a problem. While it is useful for tracking the change in prices as Table 1 indicates, it is of no real use in measuring comparative prices across countries as it suggests that in 1990, the base year, price were equal in all four countries.

By contrast, the competitiveness index provides more relevant information. For example, it shows that, in 1990, Germany was slightly more expensive than Australia and Indonesia was much less expensive as would be expected. However, by 2008 Australia had become more expensive than Germany (reflecting its rising exchange rate), and while Indonesia remained the most competitive of the group, its advantage had fallen. This is to be expected, given that Indonesia has had rapid growth in GDP in this time span and, as a developing country experiences economic growth, its prices relative to developed country prices tend to rise. The competitiveness index as shown here can be used directly in estimating demand functions for time series, cross section and panel studies.

The $\mathrm{PCI}_{\mathrm{it}}$ measures the prices facing Australian travellers though the REX does not. This hypothesis is tested in the following section, where a model of outbound tourism of Australia is developed using the panel data cointegration approach. This model is tested using data from 47 destinations, selected on the basis of data availability, as listed in Table 2. 
Table 2: Destinations included in the sample

\begin{tabular}{|l|l|l|l|l|l|}
\hline Argentina & Austria & Brazil & Cambodia & Canada & Chile \\
\hline Egypt & Fiji & France & Germany & Greece & India \\
\hline Indonesia & Ireland & Israel & Italy & Japan & Lebanon \\
\hline Malaysia & Mauritius & Mexico & Nepal & Netherlands & New Zealand \\
\hline Pakistan & Papua New Guinea & Philippines & Poland & Singapore & South Africa \\
\hline South Korea & Spain & Sri Lanka & Sweden & Switzerland & Taiwan \\
\hline Thailand & Tonga & Turkey & UAE & UK & USA \\
\hline Vanuatu & Vietnam & Western Samoa & & & \\
\hline
\end{tabular}

Source: Compiled by authors

\section{Econometric Modelling of the Demand for Outbound Tourism}

The demand equation for the total short term departures from Australia is specified as:

$\mathrm{LD}_{\mathrm{it}}=\beta_{0+\gamma} \mathrm{LD}_{\mathrm{it}-1}+\beta_{1} \mathrm{LY}_{\mathrm{t}}+\beta_{2} \mathrm{LP}_{\mathrm{it}}+\beta_{3} \mathrm{LM}_{\mathrm{it}}+\beta_{4} \mathrm{LAF}_{\mathrm{t}}+\beta_{5} \mathrm{LDH}_{\mathrm{t}}+\beta_{\mathrm{k}} \sum \mathrm{D}_{\mathrm{k}}+\tilde{\mathrm{u}}_{\mathrm{it}}$

Where $\mathrm{i}=1,2,3, \ldots .45$ representing the 45 destinations included in the sample. $\mathrm{k}$ takes the value of 2001, 2002 and 2003. The letter ' $\mathrm{L}$ ' is used to indicate that variables are in the logarithmic form. $\beta$ `s and $\gamma$ are the parameters to be estimated. Since the double logarithmic functional form is assumed for the model, $\beta_{1}, \beta_{2}, \beta_{3}, \beta_{4}, \beta_{5}$, are the respective short run demand elasticities.

$\mathrm{LD}$ is the number of short term departures.

$\mathrm{LD}_{\mathrm{t}-1}$ is the number of short term departures lagged by one year.

LY is the income variable.

$\mathrm{LP}$ is the price variable.

$\mathrm{LM}$ is the migration variable.

LAF is the transportation cost from origin to destination.

LDH is the cost of a domestic holiday in Australia.

$D_{\mathrm{k}}$ are dummy variables representing years 2001, 2002, 2003.

$\tilde{\mathrm{u}}_{i t}$ are the error terms of the regression and. $\tilde{\mathrm{u}}_{\mathrm{it}}=\tilde{\varepsilon}_{\mathrm{it}}+\tilde{\mathrm{h}}_{\mathrm{i}} \cdot \tilde{\varepsilon}_{\mathrm{it}}$ are the idiosyncratic error terms and $\widetilde{\mathrm{h}}_{\mathrm{it}}$ is an unobserved and time invariant variable that affects $\mathrm{LD}_{\mathrm{it}}$.

$L D_{i t}$ is the natural $\log$ of the number of departure to country $i . D_{i, t-1}$ is obtained by lagging $L D_{i t}$ by one period. $\mathrm{LY}_{\mathrm{t}}$ is the natural log of average weekly earnings in Australia, which is used to represent income in Australia. $\mathrm{LP}_{\mathrm{it}}$ can be alternatively proxied by (a) $\mathrm{LPCI}_{\mathrm{it}}$, which is the natural $\log$ of the competitiveness index of the destination which is calculated using Equation (3) 
and (b) LREX $_{\text {it, }}$, the log of real value of the currency of the destination in Australian dollar, calculated using Equation (1). Real exchange rate for Austria, France, Germany, Italy, Spain are calculated using the rate between Australian Dollar and Ecu, French Franc, Deutsche Mark, Lira, Peseta until 2001. As from 2002 the value of Australian dollar in EURO is considered. These data were obtained from the Reserve Bank of Australia (2010) while CPI data was obtained from the Australian Bureau of Statistics (ABS) (2010a).

$\mathrm{LM}_{\mathrm{it}}$ is the natural log of stock of migrants born at destination $\mathrm{i}$ and permanently residing in Australia at time t. This variable is calculated using the White (1997) technique. Data to calucalte this variable was downloaded from $\mathrm{ABS}(2010 \mathrm{a})$. It is assumed that, as the stock of migrants from country $i$ increases, the number of trips from Australia to country i will rise. $\mathrm{LAF}_{\text {it }}$ is the natural log of the real average roundtrip economy airfare between Sydney and a main airport of the destination. Data on airfare was obtained from Passenger Air Traffic monthly publications, adjusted by the home country CPI. The CPI of the home country were obtained from World Bank (2009)

Following Crouch (1994) and Song and Witt (2000), it is assumed that travellers will consider a domestic holiday as a substitute to an international one. Therefore, the price of the substitute in model is proxied by the Holiday Travel and Accommodation index and denoted by $\mathrm{LDH}_{\mathrm{t}}$. These data were obtained from Australian Bureau of Statistics, which constructs a weighted index of changes in the prices of domestic tourism in Australia (ABS, 2010b). Data on air, sea, bus and rail travel, car hire, holiday units, caravan parks, hotel and motel accommodation in Australia are collected at the time of purchase. The weights used are obtainable from the Australian household survey, which includes samples of 7000 households. The data used to compute the index is available on a quarterly basis and is converted into annual data by taking the average for the year (ABS, 2010b). This variable is expected to have a positive effect on short term departures since, as the cost of a domestic holiday increases, some travellers will substitute international trips. Three dummies variables included in the model, representing the years 2001 2002, 2003 as it is expected that adverse international conditions such as fear of terrorism and outbreak of SARS and Avian Flu in the region would have had a negative effect on international travel from Australia.

\subsection{Panel Unit Root Tests}


The Levin Chin Chu (LLC) (2002) and Im Pesaran and Shin (IPS) (2003) tests are performed in order to test whether the data are stationary. The test results are reported in Table 3.

Table 3: Results of Panel Unit Root Tests

\begin{tabular}{ccccc}
\hline & \multicolumn{2}{c}{ LLC } & \multicolumn{2}{c}{ IPS } \\
Variables & Level & First Difference & Level & First Difference \\
\hline LD & 2.463 & -6.920 & 3.390 & -13.430 \\
& $(0.007)$ & $(0.000)$ & $(0.999)^{\mathrm{a}}$ & $(0.000)$ \\
LY & 4.180 & 3.050 & 11.151 & 9.112 \\
& $(0.821)^{\mathrm{a}}$ & $(0.000)$ & $(0.999)^{\mathrm{a}}$ & $(0.000)$ \\
LPCI & -0.264 & -0.581 & -0.087 & -7.556 \\
& $(0.395)^{\mathrm{a}}$ & $(0.000)$ & $(0.053)^{\mathrm{a}}$ & $(0.001)$ \\
LREX & 3.371 & -10.701 & -0.087 & -8.920 \\
& $(0.067)^{\mathrm{a}}$ & $(0.000)$ & $(0.535)^{\mathrm{a}}$ & $(0.000)$ \\
LAF & -7.390 & -10.510 & -14.960 & -9.101 \\
& $(0.999)^{\mathrm{a}}$ & $(0.000)$ & $(0.947)^{\mathrm{a}}$ & $(0.000)$ \\
LM & 1.756 & 2.029 & 7.770 & 3.042 \\
& $(0.960)^{\mathrm{a}}$ & $(0.021)$ & $(0.999)^{\mathrm{a}}$ & $(0.001)$ \\
& & & & \\
LDH & -2.50 & -11.538 & -3.660 & -10.52 \\
& $(0.056)^{\mathrm{a}}$ & $(0.000)$ & $(0.999)^{\mathrm{a}}$ & $(0.000)$ \\
\hline
\end{tabular}

Source: Computed using Eviews 8. The p-values are given in parentheses. ${ }^{a}$ means failure to reject the hypothesis of the series contains unit root at least $5 \%$ level of significance.

Both tests indicate that LY, LPCI, LREX, LAF and LDH are integrated of order one, implying that the series are not stationary. The tests however, give contradicting results for LD. Hsiao (2003) suggests that the IPS test has higher power than the LLC tests. The results from IPS also suggest that some of the cross sections in LD have unit roots and that the autoregressive processes varies. It is concluded that $\mathrm{LD}$ has a unit root. Since the entire set of variables has unit roots, the next step is to perform cointegration tests to assess whether there is a long term equilibrium relationship amongst them.

\subsection{Panel Cointegration Tests}

The Pedroni (1999) panel cointegration tests are performed using the software EViews 8. To perform these tests the variables are grouped into two. Group A includes all the variables but for LREX and Group B contains all the variables but for LPCI. The results are displayed in Tables 4 and 5. V, Rho, PP and ADF are the panel cointegrating statistics. Rho, PP, ADF are the between dimension statistics. 
Table 4: Results of Pedroni Cointegration Tests

\begin{tabular}{cccccccc}
\hline & \multicolumn{3}{c}{$\begin{array}{c}\text { Panel Cointegration } \\
\text { Statistics }\end{array}$} & \multicolumn{3}{c}{$\begin{array}{c}\text { Group Mean Cointegration } \\
\text { Statistics }\end{array}$} \\
\hline \multirow{3}{*}{ Group A } & $V$ & Rho & $P P$ & $A D F$ & $R h o$ & $P P$ & $A D F$ \\
& -2.516 & -1.632 & -27.101 & -7.069 & 4.424 & -40.098 & -6.885 \\
& $(0.094)^{\mathrm{a}}$ & $(0.495)^{\mathrm{a}}$ & $(0.000)$ & $(0.000)$ & $(0.009)$ & $(0.000)$ & $(0.000)$ \\
& & & & & & & \\
Group B & -0.778 & -0.177 & -20.440 & -6.350 & 2.310 & -35.930 & -7.850 \\
& $(0.081)^{\mathrm{a}}$ & $(0.430)^{\mathrm{a}}$ & $(0.000)$ & $(0.000)$ & $(0.076)^{\mathrm{a}}$ & $(0.000)$ & $(0.000)$ \\
\hline
\end{tabular}

Source: Computed using Eviews 8. P-values are given in parentheses. ${ }^{\text {a }}$ represents the failure to reject of the null hypothesis of "no cointegration" at the $5 \%$ level of significance.

Table 4 shows that for Group A, the Panel Cointegration tests V and Rho fail to reject the null hypothesis of 'no cointegration' while the remaining tests show that the series are cointegrated. For Group B, the results show Panel Cointegration tests V and Rho and the Group Mean Rho test, fail to reject the null hypothesis of 'no cointegration' remaining tests, while the remaining test shows that the variables are cointegrated. The Group Mean Cointegration tests systematically yield higher statistics (Pedroni, 2001, 2004) for Group A and for Group B. It is concluded that there is a long run equilibrium relationship among the variables. This implies that, although the variables are not individually stationary, there exists at least one linear combination of these variables which is stationary. The model can therefore be estimated by using the variables in the level form. Estimates obtained in this manner will be reliable.

\subsection{Estimation Technique}

The sample in this study is of dimension 45 cross section and spread over 18 years. The sample is balanced, meaning that the same number of observations is available for each destination. Given the presence of cointegration in the model, the preferred estimation technique is dynamic ordinary least square (DOLS) as it will generate consistent and efficient estimators (Kao and Chiang, 2000). These researchers have demonstrated that, whilst the fully modified ordinary least squares and DOLS are the preferred techniques for estimating panel data models displaying properties of cointegration, in the case of a small sample, DOLS displays the least bias. Given that the time dimension of the sample is small, the models are estimated using DOLS. Model 1 uses the REX as a proxy for tourism prices and Model 2 uses the PCI as the proxy for prices.

Table 5: Estimation Results

\begin{tabular}{lll}
\hline VARIABLES & MODEL 1 & MODEL 2 \\
\hline
\end{tabular}




\begin{tabular}{|c|c|c|}
\hline $\mathbf{L D}_{\mathrm{t}-1}$ & $\begin{array}{c}0.232^{\text {****}} \\
(5.80)\end{array}$ & $\begin{array}{c}0.237^{* 3 * \pi / 6} \\
(5.97)\end{array}$ \\
\hline LY & $\begin{array}{l}2.13^{* * * *} \\
(8.76)\end{array}$ & $\begin{array}{c}2.39^{* * *} \\
(9.24)\end{array}$ \\
\hline LREX & $\begin{array}{l}-0.002 \\
(-0.70)\end{array}$ & \\
\hline LPCI & & $\begin{array}{c}-1.07 \\
(-2.84)\end{array}$ \\
\hline LAF & $\begin{array}{c}-0.25^{* * * *} \\
(-2.33)\end{array}$ & $\begin{array}{c}-0.14 \\
(-2.23)\end{array}$ \\
\hline LM & $\begin{array}{l}0.359 \\
(0.61)\end{array}$ & $\begin{array}{c}0.338^{\text {**** }} \\
(6.01)\end{array}$ \\
\hline LDH & $\begin{array}{c}-0.34 \\
(1.24)\end{array}$ & $\begin{array}{l}0.465 \\
(1.69)\end{array}$ \\
\hline$D_{2001}$ & $\begin{array}{l}-0.011 \\
(-0.55)\end{array}$ & $\begin{array}{l}-0.256 \\
(-1.22)\end{array}$ \\
\hline $\mathbf{D}_{2002}$ & $\begin{array}{c}-0.101^{* * *} \\
(-5.11)\end{array}$ & $\begin{array}{c}-0.089^{* * *} \\
(-4.44)\end{array}$ \\
\hline $\mathbf{D}_{2003}$ & $\begin{array}{c}-0.096^{* * *} \\
(-4.78)\end{array}$ & $\begin{array}{c}-0.027^{* * *} \\
(-4.04)\end{array}$ \\
\hline
\end{tabular}

DIAGNOSIS TESTS

Test for significance of the

\section{regression}

$\mathrm{H}_{0}$ : All the estimated coefficients are simultaneously $=0$

$$
\begin{array}{cc}
\text { Wald } \chi^{2}(9)=4970 & \text { Wald } \chi^{2}(9)=4999 \\
\left(\text { Prob }>\chi^{2}\right)=0 & \left(\text { Prob }>\chi^{2}\right)=0
\end{array}
$$

\section{Test for autocorrelation in the first} differenced errors

Durbin-Watson Statistics

$\mathrm{H}_{0}$ : No autocorrelation

Order $1: \mathrm{Z}_{1}=1.357$

Order $1: Z_{1}=1.392$

$\left(\operatorname{Prob}>\chi^{2}\right)=0.174$

$\left(\operatorname{Prob}>\chi^{2}\right)=0.164$

Source: Computed using Stata12 and Eviews 8. The student-t statistics are given in parentheses. " "***,** and * denotes significance at the 1,5 and 10 per cent significance levels" 
Estimations are carried out using Eviews 8. The coefficient obtained for income, price, airfare and immigration are the respective long term demand elasticities and the coefficient of LDH is the cross price elasticity of demand. The equations were estimated using 1 lag.

As shown in Table 5, the estimated parameters are sensitive to the choice of proxy or price. A priori, Model 2 seems to have higher predictive powers as it produces significant income, price, airfare and immigration elasticities. According to Model 1 only the income variable is relevant in explaining the variation in international departures from Australia with all other variables being statistically insignificant. The relative powers of the models are tested using the Davidson and McKinnon J-Test (1981) for non-nested models as explained in Green (2012). The following hypotheses were formulated with $\mathrm{H}_{0}$ stating that Model 1 is true while the alternative hypothesis stipulates that Model 2 is true.

$\mathrm{H}_{0} \mathrm{LD}_{\mathrm{it}}=\gamma_{1} \mathrm{LD}_{\mathrm{it}-1}+\beta_{11} \mathrm{LY}_{\mathrm{t}}+\beta_{21} \mathrm{LREX}_{\mathrm{it}}+\beta_{31} \mathrm{LM}_{\mathrm{it}}+\beta_{41} \mathrm{LAF}_{\mathrm{t}}+\beta_{51} \mathrm{LDH}_{\mathrm{t}}+\beta_{\mathrm{k} 1} \sum \mathrm{D}_{\mathrm{k}}+\tilde{\mathrm{e}}_{1 \mathrm{it}}$

$\mathrm{H}_{1} \mathrm{LD}_{\mathrm{it}}=\gamma_{2} \mathrm{LD}_{\mathrm{it}-1}+\beta_{21} \mathrm{LY}_{\mathrm{t}}+\beta_{22} \mathrm{LPCI}_{\mathrm{it}}+\beta_{23} \mathrm{LM}_{\mathrm{it}}+\beta_{242} \mathrm{LAF}_{\mathrm{t}}+\beta_{25} \mathrm{LDH}_{\mathrm{t}}+\beta_{\mathrm{k} 2} \sum \mathrm{D}_{\mathrm{k}}+\tilde{\mathrm{e}}_{2 \mathrm{it}}$

The following the procedures of Davidson and McKinnon (1981) the following equations were estimated:

$\mathrm{LD}_{\mathrm{it}}=\left(1-\mu_{2}\right)\left(\gamma_{1} \mathrm{LD}_{\mathrm{it}-1}+\beta_{11} \mathrm{LY}_{\mathrm{t}}+\beta_{21} \mathrm{LREX}_{\mathrm{it}}+\beta_{31} \mathrm{LM}_{\mathrm{it}}+\beta_{41} \mathrm{LAF}_{\mathrm{t}}+\beta_{51} \mathrm{LDH}_{\mathrm{t}}+\beta_{\mathrm{k} 1} \sum \mathrm{D}_{\mathrm{k}}\right)+\mu_{2} \mathrm{Z}_{2}$

$+\tilde{\mathrm{e}}_{1 \mathrm{it}}$

$\mathrm{LD}_{\mathrm{it}}=\left(1-\mu_{1} \mathrm{Z}_{1}\right)\left(\gamma_{22} \mathrm{LD}_{\mathrm{it}-1}+\beta_{12} \mathrm{LY}_{\mathrm{t}}+\beta_{22} \mathrm{LPCI}_{\mathrm{it}}+\beta_{32} \mathrm{LM}_{\mathrm{it}}+\beta_{42} \mathrm{LAF}_{\mathrm{t}}+\beta_{52} \mathrm{LDH}_{\mathrm{t}}+\beta_{\mathrm{k} 2} \sum \mathrm{D}_{\mathrm{k}}+\mu_{1} \mathrm{Z}_{1}\right.$ $+\tilde{\mathrm{e}}_{2 \mathrm{it}}$

The estimation results are given in Table 6 below:

Table 6: Results of J Test

\begin{tabular}{lcc}
\hline & Equation 5 & Equation 6 \\
\hline & $\mu_{2}$ & $\mu_{1}$ \\
Coefficient & 0.32 & 0.06 \\
T-Values & 2.12 & $1.77^{*}$ \\
\hline
\end{tabular}

Source: Computed using Eviews 8. The student-t statistics are given in parentheses.

* not significant at $10 \%$.

The value obtained for $\mu_{2}$ is 0.32 with t-statistics of 2.12 clearly shows that $H_{0}$ should be rejected in favour of $\mathrm{H}_{1}$. This conclusion is confirmed by the estimation results of Equation 6 which yielded a valued of 0.06 for $\mu_{1}$ with p-value of 1.77 as shown in Table 6. Model 2 which 
includes PCI as the proxy for prices is therefore retained the estimated coefficients from this model are discussed in the next section.

\section{Discussion}

The coefficient of LREX is of the expected sign but is insignificant in explaining departures from Australia. On the other hand, the PCI clearly outperforms real exchange rate as a proxy for prices in Equation 4. PCI is found to be statistically significant and is the most important determinant of departures from Australia. An elasticity value of -1.07 indicates that consumers are highly sensitive to changes in the competitiveness of the destination. A 10 percent decline in the value of this index causes departure to fall by 10.7 percent. The implication for destinations which rely heavily on Australian tourists is that, unless competitive prices are offered, Australia may decline as a market for these destinations. Most tourism demand studies suggest that the demand for tourism is, at least to a degree, elastic. This is so for a wide range of studies- of inbound tourism, of domestic tourism, and other tourism market segments. As a result, we would expect that outbound estimates would be significant and not trivially small. Our estimates using the PCI conform to this expectation, unlike those using the REX. This is consistent with the view that the wrong price variable has been used in estimating the elasticity.

It is concluded that, in this example, PCI is a better proxy for prices and that Model 2, which uses this variable, is more powerful than Model 1 and generates more robust results. Given that estimates of parameters are affected by model choice, Model 2 is retained as the preferred model. Since the more reliable price proxy, the PCI, affects other elasticities, they are also discussed here.

\subsection{Price Elasticity}

The price elasticity of demand is estimated using two proxies. In earlier studies, such as those of BTCE (1995), Smith and Toms (1978) Philips and Hamal (2000) Seetaram (2012b) and Yap (2013), the real exchange rate is found to be statistically insignificant. These results are confirmed in this study. The coefficient of REX in this study is -0.002 compared to -0.048 in Yap (2013) and -0.009 in Seetaram (2012b). These studies can give the wrong impression that Australian travellers are not sensitive to changes in tourism prices. It is more plausible to conclude that Australia travellers are price sensitive but that the real exchange rate is a poor proxy for tourism prices. This complicates the process of estimating the price elasticity of 
demand and therefore this paper offers a solution by introducing a simple method to calculate an alternative proxy for prices which yields better and more reliable results.

\subsection{Habit Persistence}

The statistical significance of the habit formation coefficient confirms that demand is subject to habit persistence. This is consistent with other studies (Song, Witt and Li, 2008). International travel from Australia is dynamic, and the inclusion of the lagged dependent variable is fully justified. The results indicate that a proportion of Australian outbound travellers tend to revisit destinations and that the word to mouth effect is high. Australian travellers share information on their trips and experience to potential travellers which leads to an increase in the number of subsequent visits. Destination managers in countries such as New Zealand, Fiji, Singapore and Malaysia, whose tourism industries rely heavily on arrivals from Australia, need to ensure that their visitors experience a high level of satisfaction, which will continue to generate growth in number of arrivals from Australia. On a technical note, this result implies that models of outbound tourism needs to include a lagged dependent or risk facing problems arising from misspecification.

\subsection{Income Elasticity}

As expected, Australian travellers view international travel as luxury consumption since an increase in real average weekly income will lead to a greater than proportionate rise in departures from Australia. This variable is the most important determinant of departures. A 10 percent increase in real weekly average income will cause departures to rise by 23.9 percent in the long run. The underlying implication is that economic growth boosts Australia's outbound travel market substantially. Australians clearly consider international trips to be luxury products. This is consistent with the great majority of demand studies that identify a relatively high value for the income elasticity of demand for travel over a wide range of origin-destination pairs (Lim, 1999; Song and Li, 2008).

\subsection{Migration Elasticity}

Based on the results from this study, it is confirmed that immigration is also a prime determinant of international departures from Australia. The trends in migration flows to Australia influence the choice of destination of Australian travellers. With some exceptions, tourism demand models do not typically account for the effect of migration- this represents an important gap in the 
tourism modelling literature. The results herein show that the effects of migration need to be included in tourism demand models of countries such as Australia, where a relatively high proportion of the resident population are born overseas. In this study, it is shown that a 10 percent rise in the proportion of Australians born overseas will lead to an expected 3.4 percent increase in the number of departures to the home country of the migrants in the long run. These elasticities may be underestimated to some extent, as the results do not incorporate the effect of second and further generations of migrants. The links between migration and tourism are explored in more detail in Seetaram (2012a).

\subsection{Airfare Elasticity}

The coefficient of the airfare variable is statistically significant and shows that the number of travellers is inelastic to changes in the cost of air travel from Australia. In fact this variable has the lowest influence on departures from Australia. If the cost of an air ticket rises by 10 percent, the number of international departures from Australia will fall by 1.4 percent showing a fairly low responsiveness of travellers to changes in the cost of air travel.

\subsection{Cross Elasticity}

The coefficient of the domestic travel and holiday index is not statistically significant in explaining the international departures from Australia, although it is of the expected sign. While a wide array of tourism products are available within Australia, the Australian traveller may still seek the experience of foreign travel because of its perceived 'glamour'. In this case, the traveller will treat not domestic holidays as a good alternative to international travel. On the other hand, this result however, contradicts those of Athanasopoulos et al (2014) who find a significant degree of substitutability between domestic holidays in Australia and international travel to Asia, the UK and the USA.

\subsection{Destination Price Competitiveness}

The results also have relevance for an issue that has been neglected in the research literature on destination price competitiveness. In general, research has focussed on the effects of prices on destination competitiveness as they influence inbound tourism flows (Dwyer et al. 2000). However, the role of prices in affecting destination competitiveness is more complex than this. A country's PCI will influence the tourism flows that it generates globally and, more particularly, to individual destinations. As argued above, an increase in this index indicates 
erosion in destination price competitiveness. While the destination becomes relatively more expensive for international travellers, discouraging travellers from visiting the destination, a high PCI also implies that the destination is likely to generate more outbound tourism. It is therefore in the interests of any destination to estimate and monitor the PCI's of its major source markets, including emerging markets, to capitalise on opportunities to access good shares of any additional tourism flows. The opportunities go beyond traditional target marketing. Given the relative ease with which PCI's for both the home and origin markets can be calculated, destination managers can add the price competitiveness index to their list of destination key performance indicators.

\section{Conclusion}

The present study was motivated by a desire to develop a correct price proxy for tourism. This is consistent with the lack of evidence of significant price elasticities of demand for outbound tourism when using the REX. Some were provided. Information on price elasticity of demand is crucial to the various stakeholders in any tourism industry. This paper suggests that this deficiency in evidence has occurred because existing demands models, for Australia and elsewhere, have used the REX as the proxy for prices. While REX is often a valid proxy for prices in (time series) models of inbound tourism, it fares poorly in models of outbound tourism. We have argued that the REX is conceptually incorrect in the outbound case, as it does not measure the relative prices of the different destinations-only the changes in prices. When it has been used, it has often found to be statistically insignificant in determining international departures, as would be expected from the theory.

The results from Model 1 in this study illustrate this, where it was found to be statistically insignificant with a coefficient approximating zero. While one econometric study does not provide proof, the regression results are consistent with the theory. The implication is that researchers can easily access this new variable which is more appropriate to measuring the price effect in demand models. This proxy for prices may be used to compare the competitiveness of two destinations and monitors the changes overtime. An additional advantage of this variable is that is easy to compute for most countries in the world and the data are freely available from sources such as the World Bank (for example in the World Development Report, Annual). 
Using the ratio of the real GDP of the destination and its GDP evaluated at PPP, to those of a base country, in this case, Australia, a PCI was constructed to represent prices in a model for outbound tourism using the panel data integration approach. Some limitations of both PPP and REX have been discussed above. Since international trade theory informs us that large deviations between the PPP and REX are unlikely to occur in the long run, more studies are needed to compare the virtues of the proposed index, based on PPP, with the standard REX approach. Unfortunately, barriers to trade (as well as potential Ricardian advantages in production) often mean one good is "cheaper" in a given country than another, so REX and PPP can and do differ. The extent to which such barriers affect PCI construction require more detailed study. In addition, the quality of the PPP data differs across destinations. Nonetheless, results to date are significant enough to encourage further exploration of the advantages of using the proposed index. In this example, the PCI outperforms the REX in that it is statistically significant and generates long term elasticities -in this case, 1.07. It is concluded that, contrary to results from previous studies, Australian overseas travellers are price sensitive. Further studies will determine whether similar results would be obtained for outbound tourism from other countries. This additional empirical work can undertake more rigorous testing of the advantages and disadvantages of the different price measures for different origin-destination pairs. Furthermore, the paper departs from the common practice in the literature of tourism demand modelling by testing for the effect of migration on the choice of destination of Australian travellers and demonstrates that its effect is highly relevant.

The advantages and disadvantages of PPP versus REX need further detailed examination in the context of construction of a PCI. While a critical comparison of PPP versus real exchange rates in general is beyond the scope of this paper, the findings of this study point to a potential use of a type of price competitiveness index that has hitherto been neglected in the research literature.

The results have implications for destination management in Australia, especially at a time when increasing numbers of residents are travelling overseas and seem to regard domestic travel as a poor substitute for 'more glamorous' locations. The more information that policy makers have regarding the determinants of this hitherto relatively neglected market, the more accurate can be forecasts of its trends. The development of the PCI also adds to our understanding of the complexities of destination price competitiveness. The method proposed above is replicable to other contexts of outbound tourism. It would be interesting to apply the above method to other economies to determine the relative strengths of the PCI and the real exchange rate as proxies 
for prices in outbound destinations, and to monitor more accurately the inter-temporal competitiveness of the home destination.

\section{References}

Athanasopoulos G. , Deng M, Li G, Song H (2014) Modelling substitution between domestic and outbound tourism in Australia: A system-of-equations approach, Tourism Management (45) pp.159- 170.

Australian Bureau of Statistics 2010a. Category 3401.0 - Overseas Arrivals and Departures, Australia,

Retrieved

from: http://www.abs.gov.au/AUSSTATS/abs@.nsf/DetailsPage/3401.0Jun\%202015?OpenDocument last retrieved in June 2010.

Australian Bureau of Statistics 2010b. Category 6401.0 Consumer Price Index, Australia, downloaded from http://www.abs.gov.au/AUSSTATS/abs@.nsf/DetailsPage/6401.0Jun\%202015?OpenDocument last retrieved in June 2010.

Bureau of Transport and Communication Economics 1995. Demand Elasticities for Air Travel to and from Australia. Working Paper 20, Department of Transport, Canberra, Australia.

Cassell, G. 1918. Abnormal Deviation in International Exchanges, Economic Journal, 28, pp. 413-15.

Cheng, K M., Kim, H., Thompson, H. (2013) The real exchange rate and the balance of trade in US tourism, International Review of Economics \& Finance, 25, pp 122-128.

Coshall, J.T. 2005. A selection strategy for modelling UK tourism flows by air to European destinations. Tourism Economics. 11(2), 141-158(18).

Crouch, G.I., 1992. Effects of Income and Price on International Tourist Demand. Annals of Tourism, 19(4), 643-664.

Crouch, G. I. 1994. Price Elasticities in International Tourism.' Journal of Hospitality \& Tourism Research, 17(3), 27Davidson, R. and J. MacKinnon. "Several Tests for Model 
Specification in the Presence of Alternative Hypotheses." Econometrica, 49(3), May 1981, 781793.

Dwyer L. and P. Forsyth, 2011. Methods of Estimating Destination Price Competitiveness: a case of horses for courses? Current Issues in Tourism 14, (8) pp 751-777.

Dwyer L., Forsyth, P. and Rao, P., 2000. The Price Competitiveness of Travel and Tourism: a comparison of nineteen destinations, Tourism Management, Special issue: the Competitive Destination, 21(1), 9-22.

Dwyer, L. N. Seetaram P. Forsyth and B. King 2014. Is the Migration-Tourism Relationship only about VFR? Annals of Tourism Research, 46, pp 130-14.

Etzo I, Massidda C. and Piras R. 2014. Migration and outbound tourism: Evidence from Italy, Annals of Tourism Research, 48, pp.235-249.

Forsyth, P. and L. Dwyer 2009. Tourism Price Competitiveness, in The Travel and Tourism Competitiveness Report: Managing in a Time of Turbulence, World Economic Forum, Switzerland, 77-90.

Forsyth, P., Dwyer, L., Seetaram, N., King, B. 2012. Measuring the Economic Impact of Migration- Induced Tourism, Tourism Analysis, 17(5), pp. 559-571.

Forsyth, P. and Seetaram, N. 2014. The Future of Australian International Aviation: Liberalisation, Competition and the Dutch Disease, in Air Transport in the Asia Pacific. Ashgate Publishing Ltd, UK.

Green, W. H. 2012. Econometric Analysis, $7^{\text {th }}$ Edition Prentice Hall, USA.

Halicioglu, F. 2010. An econometric analysis of the aggregate outbound tourism demand of Turkey, Tourism Economics, 16(1), pp. 83-97.

Im, K. S., M. H. Pesaran and Y. Shin 2003. Testing for Unit Roots in Heterogeneous Panels. Journal of Econometrics, 115 (1), 53-74. 
Kao, C. and M.H. Chiang 2000. On the estimation and inference of a cointegrated regression in panel data in : B. Baltagi (Ed.), Nonstationary Panels, Panel Cointegration, and Dynamic Panels, Advances in Econometrics, Vol. 15, JAI Press, Amsterdam, pp. 161-178.

Keating B., and A. Kriz, 2008. Outbound Tourism From China: Literature Review and Research Agenda' Journal of Hospitality and Tourism Management,15 (1) pp 32-41.

Kiviet, J.F. 1995. On Bias, Inconsistency and Efficiency of Various Estimators in Dynamic Panel Data Models. Journal of Econometrics, 68(1), 53-78.

Li, G., Song, H., and Witt, S. F. 2005. Recent developments in Econometric Modelling and Forecasting. Journal of Travel Research, 44(1). pp.82-99.

Lim, C. 1999. A Meta-Analytic Review of International Tourism Demand. Journal of Travel Research, 37(3), 273-284.

Marshall, A. 1890. Principles of Economics, $8^{\text {th }}$ Ed, Palgrave Classics in Economics, Macmillan Publishers Limited, UK.

Morley, C. 1994. The use of CPI for tourism prices in demand modelling. Tourism Management, 15 (5) pp342-346

Pedroni, P. 1999. Critical Values for Cointegration Tests in Heterogeneous Panels with Multiple Regressors. Oxford Bulletin of Economics and Statistics, 61 (Special Issue), 653-670.

Pedroni, P. 2001. Purchasing Power Parity Tests in Cointegrated Panels. The Review of Economics and Statistics, 83(4), 727-731.

Pedroni, P., 2004. Panel Cointegration; Asymptotic and Finite Sample Properties of Pooled Time Series Tests with an Application to the PPP Hypothesis. Econometric Theory, 20(3), 597625.

Phillips, B. and K. Hamal 2000. Modelling Australian Outbound Travel Demand. Paper presented at the Australian Tourism and Hospitality Research Conference, Mt. Buller, Australia.

Reserve Bank of Australia (2010), Exchange Rate, downloaded from http://www.rba.gov.au/statistics/frequency/exchange-rates.html. Last retrieved in June 2010 
Seetaram N. 2010. Computing Airfare Elasticities or Opening Pandora's Box. Research in Transportation Economics, Special Issue on Tourism and Transport, 26(1), pp. 27-36.

Seetaram, N. 2012a. Immigration and Tourism Demand: Empirical Evidence from Australia. Tourism Management, 33(6) pp. 1535-1543.

Seetaram, N. 2012b. Estimating Demand Elasticities for Australia's International Outbound Tourism, Tourism Economics, 18 (5). pp. 999-1015.

Seetaram, N. and S. Petit 2012. Panel Data Analysis, in Handbook of Research Methods in Tourism: Quantitative and Qualitative Approaches” L. Dwyer, A. Gill, N. Seetaram (eds.), Edward Elgar Publishing, UK, pp. 127-144.

Seetaram N., Song H., and Page S. 2014. "Air Passenger Duty and UK Outbound Tourism”, Journal of Travel Research , 53(4), pp. 476-487.

Seo, J. H., Park, S.Y, and Yu, L. 2009. The analysis of the relationships of Korean outbound tourism demand: Jeju Island and three international destinations. Tourism Management , 30(4), pp. 530-543.

Smith, A.B. and J.N. Toms 1978. Factors Affecting Demand for International Travel to and from Australia. Occasional Paper No 11, Bureau of Transport, Canberra, Australia.

Song H., Romilly P. and Liu X. 2000. An empirical study of outbound tourism demand in the UK' Applied Economics. 32(5),611-624

Song, H. and G. Li 2008. Tourism Demand Modelling and Forecasting-A Review of Recent Research. Tourism Management, 29(2), 203-220.

Song, H. and Witt. S. F. 2000. Tourism Demand Modelling and Forecasting: Modern Econometrics Approaches, Pergamon, Cambridge, UK.

The Economist. 1977. The Dutch Disease. Nov 26. pp. 82-83

World Bank 2009. World Development Indicators, World Bank, Washington, DC. US. Retrieved from: http://www.worldbank.org/data/countrydata/countrydata.html 
Yap G. (2013). The impacts of exchange rates on Australia's domestic and outbound travel markets, Mathematics and Computers in Simulation 93 pp. 139-150. 